\title{
THE PRESERVATION OF IOWA'S PUBLIC DOCUMENTS.
}

\author{
BY FRANK I. HERRIOTT, PH. D.
}

We appreciate a thing most when we come seriously to want it and then learn that although once obtainable in abun. dance it can not be had for love or great price. Not long is it going to be before the people of Iowa, or rather the reading public, students and investigators, realize with surprise and unspeakable regret the force of this observation as. regards the documentary records of the State.

It is no less astonishing than it is shameful, yet it is un. questionably true that, with the possible exception of the library of the State Historical Society at Iowa City there is not a library in Iowa that has a complete set of all our printed State records or public documents. The State Library does not possess them, nor does the Historical Library. But what is worse and most deplorable is the fact that these records, many of them, especially the earlier ones and not a few of those of later years, are not in our State document room, and it is difficult to secure them elsewhere even with the assistance of collectors of rare books, who charge us handsome prices for obtaining them. It is with chagrin that Iowa scholars are compelled to admit that in Madison, in the Wisconsin Historical Library, there are more complete files of some of our State records than we can boast of here in Iowa.

But stranger still, there is not an office or department in the capitol of Iowa, whose history dates back thirty years, that possesses a complete file of its printed reports to the governor or to the legislature. The Treasurer's department has a bound volume containing his reports as far back as 1856, but of few, if any, other departments can as much be said. Governor C. C. Carpenter's message in 1876 can no longer be obtained, In fact, all of the legislative documents of that year are gone. 
It cannot be said that we have not been forewarned and repeatedly urged to take suitable measures to preserve our public documents. But the anxiety of the student and investigator, who especially appreciates the inestimable value of original public records, counts for little with a busy public that usually can see only waste paper in an old House or Senate journal or committee report that may be covered with the dust and mould of a fifty years' sojourn in an attic or cellar.

In 1858, three Commissioners appointed by Governor Ralph P. Lowe under the Act of 1858 (Ch. 160, 7th G. A.), made a searching investigation of the files and the methods, work and accounts of the several State offices and reported their findings to the governor, June 1,1858 . The chairman of that commission and the author, no doubt, of the report was no less a person than our distinguished diplomat and scholar, Hon. John A. Kasson, who has always shown his keen appreciation of the value of historical data and documentary sources and the best means for their preservation. Reporting upon the results of their investigations in the governor's office the committee said:

No papers or records of the Executives of the Territorial Government are now to be found in the possession of the State Government. None of the papers or records of the Governors of the State prior to Governor Grimes, now remain in the possession of the State, so far as we can ascertain. The correspondence of this office during the term of Governor Grimes, has been preserved; bat no other papers of his term, nor books, are found in the office.

Governor Lowe has instituted efforts, which promise to be successful, to obtain the official letters and papers of Governors Lucas and Clarke, and at least a part of Governor Chambers, of the Territory. It is expected that these will contain important facts respecting the Missouri boundary question, arising from which this State has a claim on the General Government. It is not known that any other executive papers can now be. recovered.*

* Report of the Commissioners appointed to investigate the several State offices for the years 1858 and 1859 , pp $7-8$.

A part of the correspondence of the territorial governors, referred to by the com. missioners in 1858, was recently recovered from the files of the General Land Office, at Washington, as a result of the efforts of the Curator of the Historical Library, Mr. Charles Addrich, with the essistance of Iowa's congressional delegation. 
After making some specific recommendations as to the preservation of the records of the executive actions and offcial papers, the committee continues:

- . We have elsewhere referred to the need, in other State offices, of a volume of records of reports made by those offlcers to the General Assembly or to the Governor. The same necessity exists in this office for a manuscript record, well indexed by subjects, of all Executive Proclamations, and communications to the General Assembly. With the lapse of time, the printed copies may be lost: they are even now obtained with diffcalty for the earlier periods of our brief history as a State and Territory.*

The effect of that report, in which facts no matter how disagreeable they might be, were unflinchingly reported and conditions were described without reservation, had a beneficial effect that was immediately perceptible. Many of the officials acted upon the recommendations and took greater precautions to preserve systematically the records of their acts. In the next general assembly a resolution was introduced by Mr. D. D. Sabin, of Mitchell county, February 9 , 1860 , and adopted, calling for an investigation of the means then available for preserving public records, especially as against fire. On February 18, Mr. S. B. Rosenkrans, of Hamilton county, reported upon the matter, declaring the provisions inadequate for preserving the State's original and printed records, and "further protection imperatively demanded." $\dagger$ The result was the introduction of a bill for "An Act providing greater safety for books, papers and records belonging to the State," in the house of representatives, March 9,1860 . It provided for the erection on Capitol square of a building with "fire proof" vaults; but the legislature appropriated only $\$ 3,500$ for the structure. The bill passed and was approved by Governor Kirkwood April 13, 1860.

To students of origins and beginnings of institutions it is an interesting fact that the author of the original resolution that led up to the act referred to above was not its formal

*lbid, p. 8 .

†Houso Journal, 1860, p. 263.

‡Laws of 1860 , Ch. 96. 
introducer, but the then clerk of the House, who has since become well known for his interests and energetic labors along the same lines indicated in the resolution he drafted nearly forty-two years ago. To his indefatigable labors and generous donations the people of Iowa are indebted for the Aldrich Collection, and because of his industry, tact and perseverance, despite heavy odds, the State can now congratulate herself on the establishment and construction of the present Historical Library, of which he is appropriately the Curator.

Unfortunately the legislature in 1860 was parsimonious and short-sighted in appropriating so small an amount for the "Warehouse," as it was designated. A building for the safe-keeping of the State's records and documents that could be constructed within the limits of the appropriation could be neither safe nor adequate. A wooden frame veneered with brick was built. 'On the night of November 7, 1884, the warehouse, with its "fire-proof vaults," and the most of a considerable collection of public documents stored within, was destroyed by fire.

Besides that untoward event there occurred a wholesale destruction of State reports that some day will be recited with amazement by librarians deprived of valuable documents and annoyed by the incompleteness of their collections. Although many years ago, the transaction took place within the memory of men now living. The old warehouse became overstocked. Or, rather, the old capitol became crowded; more office room was needed; and it was acquired by poaching on the space of the warehouse. The matter of interest here is that various and sundry in authority came to the conclusion that the most of the documents, at least those of earlier years, stored in the building, especially constructed for their preservation, were simply so much "junk" and were better carted out. So decidedly were they of this opinion that, no one offering to buy them as waste paper, they had a man take them out, leaving a small number of each report on 
the shelves for any one who might possibly call. for them. It required more than two weeks for the man and his cart or wagon to get the documents out and load them in cars for shipment. Several cars were filled. One of the writer's informants, both witnesses of the transaction, told him that the party doing the job realized a handsome return for his labors in the sale of the documents.

Giving some reminiscences at the second reunion of the Pioneer Law-Maker's Association, in 1890, Hon. C. C. Nourse related his experiences in securing materials relating to the early history of the State in the course of the preparation of his historical address on behalf of the State of Iowa at the Centennial Exposition in Philadelphia, in 1876. Among other things he said:

. . I want to say here in this connection with that resolution [viz: one urging the legislature to colleot and preserve documents and early State records] that was adopted, when you go to find something of the early history of Iowa, and something of the archives of Iowa, do not go to the State Library. You will find in the old oapitol building, a dark room in the basement that is full of old papers from the ceiling to the floor, packed away in store boxes, mouldy and full of dust, [and] in pigeon holes. The State of Iowa ought to send some person into that dark hole, if it is there yet full of those papers, to sort out and save whatever is valuable in that subterranean treasury, and probably you will find the Journal of that convention there. [Constitutional Convention of 1846.] I have found some valuable matters in time past. I simply go to the janitor of the building when I want to find out anything there.*

The completion of the capitol in 1884 gave the State more room and a safe store-house for the annual output of official reports and public records. The inauguration of the Historical Department, in 1892, has since wrought great changes in public sentiment and practice respecting the preservation of records of the State's history. But there still prevails a practice in the distribution or disposal of our State reports that has been almost as deplorable in its results as the fire in 1884.

\footnotetext{
*Proceedings and Papers of the Second Reunion of the Pioneer Law-Makers of Iowa, at Des Moines, February 27-29, 1890, pp. 77-78.
} 
It has long been the custom to ship out all, or as many as possible, of the reports, as fast as possible. "Get rid of them," seems to be the motto. For years past, during the annual State Fairs, or at times when the capitol is crowded with visiting excursionists, one would almost invariably $\operatorname{com} \theta$ across piles of documents at various places in the basement corridors with placards thereon with the invitation in bold and staring letters, "HELP YOURSELF!" School children have been seen on the streets of the capital city indulging in sham battles with Iowa documents as missiles of offense and defense. For days thereafter the winds would whisk about the leaves and labels, covers and wrappings, of books destroyed in the melees. A waste, an utter and senseless waste of documents that will be worth, if they are not already worth, their weight in gold to the host of libraries now coming into existence in Iowa.

In defence of such extravagant distribution it will be said that there is not room enough in the basement store rooms of the capitol to keep the annual accumulations of documents. This is more or less true, although the fact does not fully justify the reckless waste of the past. The basement rooms are obviously not adapted for storage rooms and never were so intended. The State's public documents should be placed in a warehouse especially constructed for their reception and storage. Such a building could properly be a part of a Hall of Archives, a matter to be dealt with later.

With the exception of the laws and supreme court reports, and now and then an especially noteworthy document, it has never been the practice of the State Library to have set apart a certain number or proportion of each report published to be reserved entirely for the use of the library in effecting exchanges and assisting other and newly founded libraries in completing their collections. It usually takes ten to twenty years for the managements of new libraries, or their patrons, to learn to appreciate the great importance of public documents. During such time the State Library should act in 
loco parentis and preserve for them valuable records that otherwise would be lost for most of them. It is not unreasonable to assume that the world, and the State of Iowa in particular, are likely to continue for the next hundred years or more, and we should act in the interim with a view to the needs of the teeming cities and towns of our commonwealth.

If it were made a statutory duty that certain reservations: of our State documents be made as suggested and placed under the control of the State Library it would not be long before the law would prove to be an inestimable boon to our young and growing libraries. The past decade has seen a great increase in the number of libraries in Iowa. In 1885 we had 47 ; in 1895 the number had increased to 153 ; and in 1900 there were 204 reported. Under the impulse given the library movement since the enactment of the law providing for the present Library Commission, the day is not far distant when the vast majority of our towns and cities will have public libraries and the demand for the completion of sets of our State documents will be urgent, but alack for the most part without avail. Take such a recent publication as the "Official Register." None of the earlier numbers can be obtained except from the second-hand book dealers. Just recently the public has learned that the entire edition of the issue of 1901 has been exhausted.*

\footnotetext{
* Since the abovo was written the secretary of tho State Library Commission, Miss Alice S. Tyler, has issued "Leafiet No. 2," directing the attention of the librarians of the State, and of those interested in the establishment and equipping of libraries, to various sources of information relative to the history of Iowa, among others, various State publications. She especially urges the early acquisition of these valuable sources or the completion of their files. For the use of librarians there is contemplated, she informs me, a printed check list of all Iowa documents now obtainable. All this means that the libraries of Iowa are soon going to be searching far and wide for the volumes necessary to complete their files, which, but for the senseless waste of them in the past, they would be able for the most part to secure without difflculty or expense.

As a part of its work in promoting libraries the commission receives and distributes thles of the current magazines, acting in this way as a sort of clearing houso forthe libraries and book clubs of the State. If Iowa documents were included in these exchanges many rare and valuable reports could be easily recovered and many libra. ries would be enabled to complete their files or effect valuable exchanges. In every town and city of the State there may be found numbers of State documents, the possessors of which may or may not appreciate, who, if the matter were properly pre. sented, no doubt would give them to the secretary of the commission for the purposes here suggested.
} 
rotation in the clerical forces that have practical charge of the arrangement of the State's archives for reference and safekeeping, there is not always assured the utmost appreciation of the value of the State's records, either recent or ancient. They are sometimes regarded as so much lumber, and now and then treated as such. A few years ago a person in search of some information from official sources was permitted to go into the vault of the office having charge of the records he desired. He found the archives of that important officenot on the shelves properly arranged, but in an indiscriminate heap on the floor of the vault! There in confusion and neglect lay a mass of original records of the State government of Iowa covering forty years or more of her history. All sorts and sizes of record books relating to various classes of important matters of the State's business made up the heap. Covers of some of the books had been half torn off, or badly wrenched, and leaves were wrinkled, crushed and torn. The visitor asked the clerk who was assisting in searching for the desired books how long they had been left in that condition, and he replied, "Three months or so. Some men making an examination here awhile back tossed things about this way and no one has taken the trouble since to put them on the shelves, where they ought to be."

Such gross neglect of valuable records is exceptional, of course, yet to a greater or less extent the State of Iowa permits and in a way encourages precisely this sort of indifference respecting the preservation of her archives, since no suitable place is provided for them.

Persons seeking historical data or information bearing upon some claim or legal controversy, which can be obtained only from original official records, should be able to get what they seek without inconvenience or long delay. They should be able to obtain on call the original of any legislative bill or of any report of any legislative committee, with all papers and documents pertaining thereto, introduced in either the house or senate of the general assembly since Iowa became 
a State. But it is very doubtful if such is possible for many years back. In some recent researches the writer learned, much to his regret, that the original of an important house bill, introduced in 1870, had not been preserved.

With the present inadequate facilities for preserving the original documents of the State these conditions are not going to improve. From the nature of the case they are bound to get worse. The accumulations are augmenting much more rapidly in these days than was the case twenty-five years ago. The volume of work in each office has increased and there has been a marked increase in the number of offices in the capitol. Take, for instance, the offices of the board of control and of the treasurer of state. In the offices of the board is now done the work formerly done at thirteen State institutions, with much in addition, with an elaborate system of accounting for each several transaction. But besides the records and files of their own separate work there is kept a complete set of records, in duplicate, of the books in use at the various institutions under the board. The volume of work in their offices is immense, and the piling up of records and papers will very soon outgrow their present vault room. The same is to be said of the treasurer's office. The board of control act and the various acts relative to the taxation of collateral inheritances have increased a hundred fold the volume of business in that department, and to take care of his books and papers the treasurer has almost, if not quite, the poorest vault in the capitol. It is a mere "cubby hole." So many records are now in daily use in the department that two years ago it was found impracticable to keep them in the vault and a large steel book-rack with steel curtain cover was purchased and set up in the main office in which to keep them from fire and molestation. He has a large assortment of old receipt and check stubs, covering the transactions of twenty-five to forty years, that he can only pile up like so much cordwood on the topmost shelf of the vault. Should one of these stubs be called for it requires no little disagreoable labor, 
high up on a ladder, in the hot, musty air at the top of the vault, to secure the record desired.

The present capitol building is generally assumed to be fireproof, and such, for the most part, is the case; yet the risks of losses of records and documents from fire are very considerable. The furnishings of many of the offices are in wood, and the record and file cases are made of wood. About a year ago this winter, late one night, a fire was discovered in the office of the secretary of the executive council, fortunately in time to prevent any damage; but had it got under headway the records of the council for a quarter of a century would have been lost or practically ruined by water. All of the military records of the adjutant general's office are kept in wooden cases. In 1895 a fire, that started from a collection of cast-off oiled rags, destroyed the back of the case containing all of the muster rolls of our Iowa troops during the civil war. The fire was discovered before it reached the files in the case, but for the merest luck, a very valuable and indispensable collection of the State's archives would have been lost.

This state of affairs is a matter for serious consideration by the legislature. The suggestion, some time since made in these pages, ${ }^{*}$ and in the recent report of the curator of the Historical Library, that there is need of the erection of a "Hall of Archives," is most timely. For it is only in a building, especially constructed for their reception and storage, that official records can be suitably provided for, where they can be thoroughly classified, labeled, numbered, catalogued, or indexed and filed away in systematic fashion, year after year, safe from fire, theft or negligent care, and at all times easily accessible to any in search of original sources.

It is not alone the historical student and investigator who is interested in the preservation of original documentary records. Every lawyer and every litigant in the State, every man and woman who, in the future, may be involved in liti-

*Seo Ansals of Iowa, Vol V, p. 66. 
gation to protect or secure their rights, every taxpayer, have a vital interest in their maintenance and security. Life, liberty, reputation, property, when in question may rest entirely upon the authenticity and accessibility of official records. If official records are insufficient or undiscoverable, courts may resort to collateral evidence, namely, contemporary or antecedent records, for information upon which to base their conclusions respecting contested matters. ${ }^{*}$ If, therefore, constant care is not exercised on the part of the State's officers to secure and keep intact and safe from fire, dampness, decomposition, or theft, all official records and related documentary materials, individuals and corporate bodies, private and public, may suffer serious deprivation because rights assumed or claimed can not be substantiated for lack of the original records. Innumerable instances might be given. Two interesting illustrations will suffice.

From 1872 to 1874 the State of Iowa had a commission to investigate the numerous contested claims to land titles in the Des Moines river valley. The commission examined inta hundreds of claims, took an immense amount of testimony, all of which they filed with their report to Governor C. C. Carpenter in 1873. One of the members of that commission informs me that he has since received many inquiries asking for rescripts of some of the evidence collected at that time for use in legal controversies, but that the papers filed with the reports have disappeared from the office where they were deposited; at least, he has never been able to get at them if perchance they are stored away in some nook or "cubby hole" of the capitol.

At this very time, Hon. J. S. Lothrop, of Sioux City, late State Senator from Woodbury county, is prosecuting an investigation that affords striking confirmation of what has just been said respecting the vital importance of preserving the State's archives. Senator Lothrop believes that the State of

\footnotetext{
* See the case of Allen vs. Clayton, decided by the Supreme Court of Iowa in 1884, Iowa Reports, vol: 63, p. 11.
}

Vor. $\mathrm{V}-20$. 
Iowa has a substantial claim against the national government for accrued interest on the funds advanced by Iowa during the civil war in equipping troops for the government and sending them to the front earlier than otherwise they could have been. Iowa advanced large amounts to assist in that work, borrowing $\$ 300,000$ and in still other ways extending her credit to the nation. Repayment of the principal of her outlay, although ultimately made, was long delayed and the State was never reimbursed for the interest she paid out on her loans and the other sums-advanced. In making his researches for evidence on which to rest his claim, Senator Lothrop experienced some difficulty in obtaining the official records during some portions of the period he was investigating. Prior to 1863 many of the records in both the auditor's and treasurer's offices are missing. The point to be noted here is that the inquiry he has made may mean several hundred thousand dollars to our State treasury. Recent decisions of the court of claims at Washington respecting the claims of other states similarly urged have been adjudged favorably to the claimants. But the State of Iowa must rest her claim upon old and musty records, not always carefully kept. If success attends Senator Lothrop's quest, the State will realize nearly enough to build a Hall of Archives comparable in architectural dimensions and attractiveness with the plan of the Historical Library. This financial phase of the preservation of archives should lessen the size of the obstacle which no doubt looms large in the minds of taxpayers and their representatives, when the erection of such a building is urged.

THE IDOL of to-day pushes the hero of yesterday out of our recollection, and will in time be supplanted by his successor of to-morrow.-Washington Trving. 
Copyright of Annals of Iowa is the property of State of Iowa, by \& through the State Historical Society of Iowa and its content may not be copied or emailed to multiple sites or posted to a listserv without the copyright holder's express written permission. However, users may print, download, or email articles for individual use. 